\title{
PESANTREN; PRESPEKTIF SEJARAH, KONSTRIBUSI DAN MODEL PENDIDIKAN
}

\author{
P-ISSN: 2085-4536 | E-ISSN: 2721-7183 \\ Link: https://jurnal-stidnatsir.ac.id/index.php/dakwah/article/view/62 \\ DOI : https://doi.org/10.38214/jurnaldawahstidnatsir.v3i01.62 \\ Dikirim: 01-05-2020 Direview: 01-05-2020 \\ Diterbitkan: 06-05- \\ 2019 \\ ABDUL KADIR \\ kadir@stidnatsir.ac.id \\ STID Mohammad Natsir, Indonesia
}

Tujuan Penelitian: Penelitian ini bertujuan untuk menelusuri sejarah dan konstribusi pesantren serta model-model pendidikan yang ada di pesantrean tradisonal dan modern di indonesia. Metode Penelitian: Kualitatif. Hasil Penelitian: Pesantren terlihat unik dan menarik, memiliki ciri khusus dan ada tradisi tersendiri yang berbeda dengan model pendidikan umum. Sistem pengajaran yang dilakukan di pesantren seringkali tidak menggunakan kurikulum, atau target tertentu dan kurikulum semuanya diserahkan pada masing-masing kiai. Dan umumnya materi yang disampaikan itu lebih banyak bermuatan bahasa Arab 'kitab kuning'. Dan seringkali keberadaan masjid dalam sebuah komplek pesantren lebih dahulu ada dibandingkan dengan keberadaan pesantren itu sendiri. Oleh karenanya, masjid merupakan instrumen awal sebuah pesantren. Karena di situ lah biasanya para kiai mendidik para santrinya. Dan pesantren secara umum terbagi dalam dua model. Model tradisional dan modern.

Kata Kunci: Pesantren, sejarah, konstribusi, model pendidikan.

\section{PENDAHULUAN}


Tidak bisa disangkal bahwa kontribusi pesantren di Indonesia tidaklah sedikit. Sejak awal penjajahan sampai kemerdekaan Indonesia diraih, kontribusi pesantren begitu besar dalam meraih kemerdekaan, juga dalam pendidikan Islam di Indonesia.

Entah berapa banyak peneliti baik dari Indonesia maupun asing yang menulis tentang pesantren, apakah dari segi sejarah, asal-usul, peran dan kontribusi pesantrean di Indonesia. Dari hasil penelitian itu berserakan buah karya yang bisa kita temukan dalam khasanah kepustakaan Indonesia. Mereka membahas dari prespektif sejarah, peran dan model pendidikan di pesantren. Terkadang pesantren tradional misalnya, terlihat unik dan menarik, ada tradisi khusus yang berbeda dengan model pendidikan umum yang ada di Tanah Air.

Jika kita membahas tentang pesantren - sebagai wahana pendidikan Islam tertua - di Indonesia, mau tidak mau seringkali kita merujuk diantaranya pada tulisan-tulisan Zamaksyari Dhofier, Manfred Ziemek, Martin Van Bruisessen dan yang lainnya. Ketiganya banyak meneliti tentang pesantren, seluk-beluk, tradisi-tradisi, ketradisionalanya dan juga peran dan kontribusinya di Nusantara. Bila merujuk kepada mereka tentang pesantren di Indonesia dan seluk beluknya. Banyak sekali literatur tentang pesantren yang justru ditulis oleh sarjana barat, dan itu bisa kita lihat dalam literatur kepesantrenan dan ke-Indonesian.

Terlihat dominasi sarjana barat tentang pesantren amat kentara. Dari sekian peneliti tentang pesantren, satu dua adalah asli sarjana Islam Indonesia. Tetapi, literatur yang digunakan tetap saja memakai hasil kajian sarjana barat. Ini yang mestinya kita balik. Penulis lokal Nusantara yang mestinya mendominasi. Mengapa seperti itu, karena pesantren adalah indentitas Islam dan kaum muslimin.

Karena keterbatasan literatur, mereka para penulis lokal seringkali banyak yang menyandarkan pada hasil penelitian sarjana-sarjana barat 
tentang pesantren di Indonesia. Para sarjana barat banyak mengkaji dan meneliti tentang pesantren terutama pesantren-pesantren di pulau Jawa. Walaupun ada sebagian dari mereka adalah sarjana-sarjana Islam Indonesia. Tetapi, mereka relatif masih sedikit. merekalah yang banyak menelusuri jejak pesantren di Jawa dan pulau-pulau lainnya di Nusantara. Itulah kenyataan sejarah yang ada dalam literatur pesantren di Indonesia.

Zamaksyari Dhofier, dalam bukunya Tradisi Pesantren menyebutkan, sedikit sekali yang dapat diketahui tentang perkembangan pesantren di masa lalu sehingga kita hanya bisa menduga-duga tentang ciri-ciri dan pengaruhnya dalam kehidupan keagamaan orang Jawa. Kelompok-kelompok pengajian untuk anak-anak, nampaknya sudah merupakan fenomena yang cukup tua, setua datangnya Islam di Indonesia, walaupun jumlahnya tentu masih sangat terbatas. ${ }^{1}$ Inilah yang menjadi kenyataan literatur tentang pesantren menunjukan masih sangat sedikit.

Pesantren adalah lembaga pendidikan Islam tertua yang telah berfungsi sebagai salah satu bentang pertahanan umat, pusat dakwah dan pusat pengembangan muslim di Indonesia. ${ }^{2}$

Asal-usul dan kapan tepatnya keberadaan dan munculnya pesantren di Indonesia sendiri belum bisa diketahui secara pasti. Salah satu peneliti tarekat dan tradisi Islam Indonesia, asal Belanda, Martin $V$ an Bruinessen, menyatakan bahwa asal usul pesantren sangat sedikit. Dan tidak diketahui kapan lembaga itu muncul pertama kali di Indonesia. $^{3}$

\footnotetext{
${ }^{1}$ Zamakhsari Dhofier, Tradisi Pesantren Studi tentang Pandangan hidup Kyai, (Jakarta: LP3ES, 1994, cet. ke-6., hal 33-34.

${ }^{2}$ Ensiklopedi Islam (Jakarta: 1993, Ichtiar Baru van Hoeve), hal 99.

${ }^{3}$ Martin Van Bruisessen, Kitab Kuning Pesantren dan Tarekat Tradisi-tradisi Islam di Indonesia, (Bandung: Mizan, 1999, cet. 3) hal 23.
} 
Namun banyak pihak yang menyebut asal mula pesantren sudah berada pada abad ke-16, dengan berpijak pada sejarawan dan peneliti seperti Pigeud dan de Graaf - yang banyak mengamati tradisi dan kondisi masyarakat Jawa. Banyak data dan catatan sejarah tentang munculnya pertama kali pesantren pada abad ke-16. Namun, klaim itu masih diragukan keakuratannya dan masih dipertanyakan, seperti dikemukakan Martin Van Bruinessen itu. ${ }^{4}$

Salah satu nama tempat pendidikan Islam tradisional di Indonesia adalah pesantren. Menurut Dhofier, sebelum tahun 1960-an, pusatpusat pendidikan pesantren di Jawa dan Madura lebih dikenal dengan nama pondok. Istilah pondok barangkali berasal dari pengertian asramaasrama para santri yang disebut pondok atau tempat tinggal yang dibuat dari bamboo,(baca; bambu) atau barangkali berasal dari kata Arab funduq, yang berarti hotel atau asrama. ${ }^{5}$

Menurut Manfred Ziemek, secara etimologis nama pesantren berasal dari pe-santri-an yang makna 'tempat santri'. Ada anggapan, bahwa tempat pendidikan ini berasal dari masa sebelum Islam, serta mempunyai kesamaan dengan Budha dalam bentuk asrama. ${ }^{6}$

Dhofier, seperti mengutif pendapat Prof. Johns menyebutkan bahwa istilah itu (santri) berasal dari bahasa tamil, yang berarti guru mengaji. ${ }^{7}$ Sedangkan C.C. Berg berpendapat, istilah tersebut berasal dari

\footnotetext{
${ }^{4}$ Martin Van Bruisessen, Kitab Kuning Pesantren dan Tarekat Tradisi-tradisi Islam di Indonesia, Ibid, hal 23-25. lihat pula Republika, Khazanah, Geneologi Sejarah Pesantren, Senin, 4 Februari 2008, hal 8.

${ }^{5}$ Zamakhsari Dhofier, Tradisi Pesantren Studi tentang Pandangan hidup Kyai, Ibid, hal 18.

${ }^{6}$ Dr. Manfred Ziemek, Pesantren dalam perubahan social, (Jakarta: P3M, cet. 1, 1986), hal 16. dan karya ini merupakan desertasi Doctor pada Universitas di Jerman.

${ }^{7}$ Zamakhsari Dhofier, Tradisi Pesantren Studi tentang Pandangan hidup Kyai,Tradisi Pesantren Studi tentang Pandangan hidup Kyai, hal 18.
} 
shastri yang dalam bahasa India berarti orang yang tahu buku-buku suci agama Hindu atau seorang sarjana ahli kitab suci agama Hindu. ${ }^{8}$

Biasanya pesantren didirikan oleh para pemerakarsa kelompok belajar, yang mengadakan perhitungan dan memperkirakan kemungkinan hidup bersama bagi para santri dan ustadz. Maka berdirilah sebuah pondok, tempat yang tetap untuk hidup bersama masyarakat pelajar. Dengan kata 'pondok' orang membayangkan 'gubuk' atau 'saung bambu', suatu lambang yang baik tentang kesederhanaan sebagai dasar perkiraan kelompok. Di sini guru dan murid setiap hari berkumpul dan dalam waktu yang lama bersama-sama menempuh kehidupan di pondok ini.

Satu hal yang unik dari pesantren, menurut penulis adalah - dan yang membedakannya - antara pesantren dengan sekolah atau madrasah. Kalau pesantren keberadaannya kadangkala mendahului adanya komunitas masyarakat setempat. Tetapi, berbeda dengan sekolah, keberadaannya karena kebutuhan masyarakat setempat itu sendiri.

Menurut tradisi pesantren, pengetahuan seseorang diukur oleh jumlah buku yang telah dipelajarinya dan kepada ulama mana ia telah berguru, terlebih bila berguru pada ulama/kiai yang terterkenal. Tentunya, buku-buku yang digunakan adalah buku standar dalam tulisan bahasa Arab. ${ }^{10}$

Sistem pengajaran yang dilakukan di pesantren dalam tahap ini tidak menggunakan kurikulum, atau target tertentu sebagaimana kita saksikan sekarang ini. Kurikulum atau target semuanya diserahkan pada masing-masing ulama/kiai.

\footnotetext{
${ }^{8}$ Zamakhsari Dhofier, Tradisi Pesantren Studi tentang Pandangan hidup Kyai, Ibid, hal 18

${ }^{9}$ Manfred Ziemek, Pesantren dalam perubahan social, hal 18.

${ }^{10}$ Zamakhsari Dhofier, Tradisi Pesantren Studi tentang Pandangan hidup Kyai, hal
} 22. 
Tetapi menurut Dhofier, metode utama sistem pengajaran dilingkungan pesantren ialah menggunakan system bandongan atau seringkali juga disebut dengan system weton. Dalam sistem ini sekelompok murid antara 5 sampai dengan 500 mendengarkan seorang guru yang membaca, menerjemahkan, menerangkan dan seringkali mengulas buku-buku Islam dalam bahasa Arab. Kelompok dari system bandongan ini disebut halaqoh, yang berarti lingkaran murid, sekelompok siswa yang belajar di bawah bimbingan seorang guru. Dalam pesatren kadang-kadang diberikan juga sistem sorogan tetapi hanya diberikan pada santri-santri baru yang masih memerlukan bimbingan individual. ${ }^{11}$

Kajian tentang pesantren ini, penulis melihat Zamakhsyari Dhofier dalam bukunya itu, menarik, analisis dan cukup dalam soal pesantren, begitu juga Manfred Ziemek dan Martin Van Bruinessen.

\section{HASIL DAN DISKUSI}

Dalam sebuah pesantren baik yang tradisional maupun yang sudah modern biasanya mempunyai lima unsur penting. Kelima unsur penting itu adalah; Pertama: Pondok (asrama untuk santri). Kedua: masjid (sebagai tempat ibadah dan juga tempat proses belajar mengajar). Ketiga: Santri. Keempat: Kiai, ajengan atau ulama (sebagai tokoh utama dalam pesantren). Kelima: Pengajian kitab kuning. Kelima ciri tersebut, yang sangat dominan di Jawa dan juga Aceh serta Sumatra Barat, walaupun dengan istilah yang sedikit berbeda. ${ }^{12}$

Pesantren adalah suatu bentuk lingkungan "masyarakat" yang unik dan memiliki tata nilai kehidupan yang positif. Pada umumnya, pesantren terpisah dari kehidupan sekitarnya. Komplek pesantren

\footnotetext{
${ }^{11}$ Zamakhsari Dhofier, Tradisi Pesantren Studi tentang Pandangan hidup Kyai, Ibid., hal 28.

${ }^{12}$ Fuad Jabali dan Jamhari (penyu), IAIN Modernisasi Islam di Indonesia (Jakarta: 2002, Logos), hal 95.
} 
minimal terdiri atas rumah kediaman pengasuh -disebut juga kiai (Jawa), ajengan (Sunda), dan bendoro (Madura)--, masjid atau mushola, dan asrama santri. Tidak ada model atau patokan tertentu dalam pembangunan fifik pesantren. Sehingga penambahan bangunan demi bangunan dalam lingkungan pesantren hanya mengambil bentuk improvisasi sekenanya belaka. ${ }^{13}$

Lebih lanjut Wahjoetomo, menyebutkan, meskipun dalam kondisi fisik yang sederhana, pesantren ternyata mampu menciptakan tata kehidupan tersendiri yang unik, terpisah, dan berbeda dari kebiasaan umum. Bahkan, lingkungan dan tata kehidupan pesantren dapat dikatakan sebagai subkultur tersendiri dalam kehidupan masyarakat sekitarnya.

Meskipun dalam kondisi fisik yang sederhana, pesantren ternyata mampu menciptakan tata kehidupan tersendiri yang unik, terpisah, dan berbeda dari kebiasaan umum. Bahkan, lingkungan dan tata kehidupan pesantren dapat dikatakan sebagai subkultur tersendiri dalam kehidupan masyarakat sekitarnya.

Ada beberapa hal yang menguatkan pernyataan ini. Pertama, Jadwal kegiatan dan kehidupan "masyarakat" pesantren berbeda dengan masyarakat pada umumnya. Jadwal kegiatan pokok di pesantren, yakni pengajian kitab kuning dan aktivitasnya lainnya, tidak didasarkan atas satuan jam, melainkan berdasarkan waktu shalat wajib (shalat maktubab). Telaah kitab dilakukan setiap selesai mengerjakan shalat lima wajib, sedangkan kegiatan-kegiatan lain harus disesuaikan dan tunduk pada penjadwalan tersebut. Dengan jadwal semacam ini, dengan lamanya satu shalat dengan shalat lain tidak sama, maka pembagian waktu pengajian juga berbeda. Pelajaran dan kegiatan pada malam hari lebih lama dari

\footnotetext{
${ }^{13}$ Lihat Wahjoetomo, Perguruan Pesantren Pendidikan Alternatif Masa depan, (Jakarta: 1997, GIP, Cet. 1) hal 65.
} 
waktu petang (asar) dan fajar (subuh). Sehingga para santri lebih banyak "bekerja" pada waktu malam karena kondisi tersebut.

Dengan pembagian waktu yang unik ini, muncullah pola kehidupan yang khas dan mungkin tidak lumrah bagi pandangan orang di luar pesantren. Misalnya : Mencuci pakaian pada waktu matahari hampir terbenam atau menanak nasi pada tengah malam. ${ }^{14}$

Kedua, Struktur dan kurikulum pengajaran yang diberikan. Sistem pengajaran pesantren, dari tingkat ke tingkat, tampaknya hanya merupakan pengulangan tak berkesudahan. Masalah yang dikaji hanya itu-itu saja, meski kitab yang digunakan berbeda. Diawali dengan mabsutat (kitab kecil) yang berisi teks ringkas dan sederhana, kemudian mutawassitat (kitab sedang) yang berisi penjelasan-penjelasan mengenai makna dan maksud dari kitab-kitab mabsutat, dan terakhir muthawalat yang berisi hasil pemikiran para mujtahid dan proses pemikirannya.

Seorang kiai menyampaikan pengajaran untuk berbagai level pengkajian, dan para santri dipersilahkan memilih yang ingin ditelaahnya. Seorang santri membutuhkan waktu bertahun-tahun bila ia ingin mengikuti semua pelajaran. Dalam tradisi pesantren, keseluruhan struktur pengajian tidak ditentukan oleh lama tidaknya seorang santri mengikuti pengajian kiranya --karena tidak ada keharusan menempuh ujian atau meraih gelar dari kiai-melainkan oleh ketundukan dan kemampuan santri dalam menimba ilmu dari kiai. Itulah sebabnya, kebesaran dan keagungan seorang kiai tidak diukur dari segi jumlah lulusan santrinya, tetapi dari banyaknya santri yang menjadi "orang besar" di kemudian hari.

Ketiga, Model penyampaian dan penggunaan materi yang telah dikuasai santri. Pelajaran diberikan dalam bentuk kuliah terbuka. Kiai

\footnotetext{
${ }^{14}$ Wahjoetomo, Perguruan Pesantren Pendidikan Alternatif Masa depan, Ibid, hal 65-66.
} 
membaca, menerjemahkan, dan menerangkan isi kitab. Kemudian para santri membaca ulang kitab tersebut, entah di hadapan kiai, di biliknya, atau dalam pengajian ulang antar santri selevel.

Semua materi pengajian di pesantren bersifat aplikatif yang dituntut pengalamannya dalam kehidupan sehari-hari. Sehingga penekanannya bukanlah pada banyaknya materi atau kemampuan santri dalam memahami isinya, melainkan pada penerapan dalam kehidupan mereka. Penekanan ini disebut "kemanfaatan ilmu" atau "ilmu manfaat" dalam terminologi pesantren. Karena hampir tidak ada satu bidang pun yang tidak tersentuh oleh aplikasi pengajian yang diberikan mulai dari cara menyucikan diri untuk melakukan ibadah ritual hingga ketentuan prosedural tata niaga yang diperkenankan oleh agama, maka pengajian di pesantren merupakan sebuah proses pembentukan tata nilai yang lengkap, dengan orientasi dan penilaian sendiri.

Dengan model dan tata cara pengajian yang unik dan khas seperti itu, berakarlah pandangan hidup yang unik dan khas pula di kalangan warga pesantren, yaitu visi untuk memperoleh penerimaan Allah diakhirat kelak, yang dalam pesantren dikenal dengan istilah "ikhlas". Mereka dengan tulus apat menerima kadar yang diberikan oleh kehidupan, terutama bila dipandang dari sudut kehidupan, terutama bila dipandang dari sudut kehidupan material, asalkan kebutuhan ukhrawi terpuaskan. $^{15}$

Hal ini mungkin kedengaran aneh dan fatalistik, minimal bagi orang-orang yang belum pernah mengenyam kehidupan pesantren. Akan tetapi, pandangan hidup tersebut ternyata membawa pengaruh positif, yakni kemampuan menerima perubahan-perubahan status dengan mudah dan fleksibilitas santri untuk menempuh karier masing-

\footnotetext{
${ }^{15}$ Ibid, hal 67.
} 
masing setela menamatkan studi di pesantren. Hambatan-hambatan psikologis yang acapkali berupa pretensi-pretensi etnis yang kaku di kalangan nosantri, hanya sedikit dijumpai dalam kehidupan pesantren. Dengan demikian, dalam pesantren telah terdapat dinamisme yang bersifat adaptif terhadap kemajuan eksternal.

Dengan pola kehidupan yang unik inilah pesantren mampu mempertahankan penerapan nilai-nilainya selama berabad-abad. Karena itu, dalam jangka panjang, institusi pesantren berada dalam kedudukan kultural yang relatif lebih kuta dari pada masyarakat lainnya. Pesantren mampu melakukan transformasi total dalam sikap hidup masyarakat, tanpa harus mengorbankan identitasnya. Bila kita mengamati pola pertumbuhan pesantren, hampir setiap pesantren menunjukkan kemampuan melakukan transformasi tersebut. Bermula dari sebuah masjid kecil atau mushalla, pesantren kemudian berkembang menjadi sebuah lembaga masyarakat yang berperan dominan dalam pembentukan tata nilai bersama yang berlaku bagi kedua belah pihak, yaitu masyarakat dan pesantren.

Keempat, sistem hierarki kekuasaan. Dalam kehidupan pesantren, kiai adalah satu-satunya pemegang hirarki kekuasaan yang diakui. Meskipun begitu, tidak berarti seorang kiai dapat berbuat semaunya secara otoriter. Ini karena kekuasaan kiai tidaklah ditegakkan di atas kekuatan senjata atau melalui SK presiden, melainkan di atas kewibawaan moral. Konsekuesinya, kiai dituntut agar mampu menjadi penyelamat para santri dari melakukan kesesatan. Dengan demikian, kedudukan kiai dalam pesantren bukanlah sebagai penguasa, melainkan pembimbing bagi para santrinya dalam berbagai hal. Seorang kiai dituntut pula untuk berperan sebagai peneliti, penyaring, dan asimilator aspek-aspek kebudayaan dari luar yang memasuki pesantren. Sehingga 
moral santri dan kehidupan pesantren tetap berjalan sesuai dengan norma-norma Islam. ${ }^{16}$

Kepribadian dan sikap ikhlas pada diri kiai juga merupakan syarat mutlak bagi para santri. Ini karena pada hakikatnya santri adalah orang yang menyerahkan diri pada kiai untuk dididik menjadi muslim yang baik. Ia harus menjalani segala peraturan di pesantren dengan penuh kerelaan dan kesadaran (ikhlas). Sehingga ia dapat memperoleh barokah atau keberhasilan dalam menuntut ilmu.

Kehidupan pesantren yang diwarnai sikap zuhud dan dikombinasi dengan kesediaan melakukan segala peraturan untuk memperoleh berkah ini, akan sangat membekas dalam jiwa santri. Bekas tersebut akan membentuk sikap hidupnya di kemudian hari. Sikap hidup bentukan pesantren ini bila diperkenalkan kepada masyarakat luar dapat menjadi pilihan ideal bagi sikap hidup rawan yang serba tidak menentu, yang merupakan ciri utama kondisi serba transional dalam masyarakat Indonesia kontemporer. Inilai kelebihan pesantren dari berbagai lembaga pendidikan umum.

Karena itulah, pesantren diasumsikan sebagai simbol keterbelakangan dengan para santrinya yang kolot dan pemikirannya hanya berkisar pada soal halal-haram saja. Akan tetapi, belakangan ini telah terjadi perubahan, apresiasi terhadap pesantren terus meningkat. ${ }^{17}$ Sesuai dengan perkembangan dan kemajuan zaman.

\section{SEJARAH PESANTREN INDONESIA}

Menelusuri sejarah pesantren adalah sesuatu yang tidak mudah. Selain literatur yang sedikit juga, jejak untuk melacaknya pun adalah sesuatu yang tidak mudah. Zamaksyari Dhofier, melihat, sedikit sekali

\footnotetext{
${ }^{16}$ Lihat Wahjoetomo, Ibid 68-69.

${ }^{17}$ Wahjoetomo, ibid, hal 69.
} 
yang dapat kita ketahui tentang perkembangan pesantren di masa lalu sehingga kita hanya bisa menduga-duga tentang ciri-ciri dan pengaruhnya dalam kehidupan keagamaan orang Jawa. Kelompokkelompok pengajian untuk anak-anak, nampaknya sudah merupakan fenomena yang cukup tua, setua datangnya Islam di Indonesia, walaupun jumlahnya tentunya masih sangat terbatas. Dengan demikian jumlah pesantren akan lebih terbatas lagi. ${ }^{18}$

Banyak para sarjana yang berpendapat bahwa pada waktu abadabad pertama sejarahnya, Islam lebih banyak merupakan kegiatan tarekat, di mana terbentuk kelompok-kelompok organisasi tarekat yang melaksanakan amalan-amalan dzikir dan wirid. Dimana para kiai pimpinan tarekat mewajibkan pengikut-pengikutnya untuk melaksanakan suluk selama 40 hari dalam satu tahun. Untuk keperluan suluk ini, para kiai menyediakan ruangan-ruangan khusus untuk penginapan dan tempat memasak di kiri-kanan masjid. Di samping amalan-amalan tarekat, pusat-pusat pesantren semacam itu juga mengajarkan kitab-kitab dalam berbagai cabang pengetahuan agama Islam kepada sejumlah pengikut-pengikut inti. Dhofier pun, melihat, lembaga-lembaga pengajian untuk anak-anak dan lembaga-lembaga pesantren yang menjadi pusat-pusat organisasi tarekat ini tidak bisa dipisahkan satu dengan yang lain. Keduanya saling menunjang dan merupakan satu kesatuan struktur dalam sistem, pendidikan Islam tradisional pada waktu itu. Yang menarik untuk diperhatikan ialah bahwa sistem madrasah yang berkembang di negara-negara Islam yang lain sejak permulaan abad ke-12, tidak pernah muncul di Jawa sampai dengan permulaan abad ke-20. Tetapi menurut karya-karya sastra Jawa klasik seperti Serat Cabolek, Serat Centini dan lain-lain, paling tidak

\footnotetext{
${ }^{18}$ Zamakhsari Dhofier, hal 33-34.
} 
sejak permulaan abad ke-16 telah banyak pesantren-pesantren yang masyhur yang menjadi pusat-pusat pendidikan Islam.

Pesantren-pesantren ini mengajarkan berbagai kitab Islam klasik dalam bidang jurisrudensi, teologi dan tasawwuf. Kiranya cukup alasan untuk menyimpulkan bahwa, tidak seperti keadaan di negara-negara Arab, tradisi pesantren Jawa sejak bentuknya yang paling tua telah merupakan suatu kombinasi antara madrasah dan pusat kegiatan tarekat. Dan pola kombinasi madrasah dan tarekat inilah yang akhirnya tumbuh di Jawa, yang tidak mempertentangkan antara aspek syariah dan aspek tarekat. Sebelum tumbuhnya Islam moderen, di Jawa tidak muncul dikotomi antara ulama ahli syara' dan ulama ahli Sufi. Barangkali karena bentuk Islam yang seperti inilah di Jawa perkataan kiai lebih lazim dipakai daripada perkataan ulama. Gelar "kiai" ini dalam lingkunga pesantren dipakai untuk menunjuk seorang sarjana muslim yang menguasai bidang-bidang tauhid, fiqh dan sekaligus juga seorang ahli Sufi.

Laporan Pemerintah Belanda tahun 1891 tentang lembagalembaga pendidikan penduduk “Asli” Jawa, mencatat jumlah lembagalembaga Islam tradisional-pengajian, pesantren dan jumlah muridmuridnya di wilayah-wilayah kabupaten yang kuat keislamannya. Tetapi laporan ini tidak membedakan antara pengajian dan pesantren. Van der Chijs menulis bahwa sejumlah besar lembaga-lembaga ini mengajarkan tidak lebih dari pembacaan al-Qur'an, dan hanya sebagian kecil muridmurid diajarkan menulis Arab. ${ }^{19}$

Van den Breg, sebagaimana dikutif Dhofier, rupanya telah menyadari perbedaan atau tingkatan dalam sistem pendidikan Islam tradisional. Ia berusaha menganalisa statistik resmi pemerintah tahun

\footnotetext{
${ }^{19}$ Ibid, hal 35.
} 
1885 yang mencatat jumlah lembaga-lembaga Islam tradisional sebanyak 14.929 di seluruh Jawa dan Madura (kecuali Kesultanan Yogyakarta) dengan jumlah murid kurang lebih 222.663 orang.

Menurut pendapatnya, 4/5 dari jumlah lembaga tersebut merupakan lembaga pengajian dasar yang mengajarkan pembacaan Qur'an. Kemudian 3000 dari jumlah tersebut merupakan pendidikan menengah yang mengajarkan dasar-dasar bahasa Arab dan kitab-kitab pengetahuan agama tingkat dasar, antara lain Kitab Safinah Al-Najah Sullam al-Taufiq, dan Sharah Al-Sittin. Kemudian 300 dari jumlah tersebut ia golongkan sebagai lembaga-lembaga pesantren. Pesantrenpesantren ini mengajarkan pendidikan tingkat tinggi mengenai kitabkitab Islam klasik. Untuk lembaga-lembaga tingkat dasar dan menengah banyak terdapat murid-murid perempuan, sedangkan lembaga-lembaga pesantren menyediakan pendidikan hanya untuk murid laki-laki. ${ }^{20}$

Dalam sejarah Islam di Jawa, akhir abad ke-19 juga dikenal sebagai munculnya semangat baru dalam kehidupan keagamaan (religious revivalism). Sebagai akibat dari bertambahnya jumlah haji, guru-guru ngaji, dan murid-murid pesantren, tumbuh pula kesadaran bahwa Islam dapat memberi sumbangan bagi tumbuhnya proto-nasionalisme. Keadaan sosial ekonomi, kebudayaan dan politik di Jawa sebagai akibat politik Belanda menumbuhkan kesadaran kebangunan Islam tersebut. Menurutnya peranan pemimpin-pemimpin pribumi sebagai akibat dari konsolidasi kekuasaan Belanda, dimana boleh dikatakan bahwa para pemimpin bumi ini akhirnya hanya sekedar menjadi alat Belanda, telah memperdalam jurang antara rakyat dan pemimpin pribumi. Semakin terseretnya pemimpin pribumi ke dalam kekuasaan belanda, juga mengakibatkan para pemimpin ini dikucilkan dari Islam. Para priyayi

\footnotetext{
${ }^{20}$ Ibid, 35-36.
} 
yang bersikap lebih menyenangkan para penguasa asing, begitu berhatihati untuk menghindari kecurigaan Belanda untuk berhubungan dengan orang orang yang dicap oleh Belanda "orang-orang fanatik"; akibatnya mereka menjadi sasaran penghinaan para ulama, dan untuk selanjutnya kehilangan hubungan yang baik dengan Islam.

Di samping itu, perkembangan yang cukup penting ialah, sejak pertengahan abad ke-19 tersebut, banyak sekali anak-anak muda dari Jawa yang tinggal menetap beberapa tahun di Mekah dan Medinah untuk memperdalam pengetahuan mereka. Bahkan, banyak diantara menjadi ulama yang terkenal dan mengajar di Mekah atau di Madinah. Karena para ulama dari Jawa ini akhirnya turun aktif dalam alam intelektualisme dan spritualisme Islam yang berpusat di Mekah, mereka juga mempengaruhi perubahan watak Islam di Jawa. Dan dengan makin kuatnya keterlibatan mereka dalam kehidupan intelektual dan spiritual Timur Tengah, Islam di Jawa makin kehilangan sifat-sifatnya yang lokal dan titik-beratnya pada aspek tarekat. Semakin berkurang (walaupun tidak berarti hilang sama sekali). Bertambahnya pengetahuan serta pengalaman mereka dalam hal perbedaan praktek-praktek ritual dan doktrin, menyebabkan watak keislaman yang lebih toleran, tapi juga lebih seirama dengan watak Islam di Timur Tengah. Ini tidak berarti bahwa Islam di Jawa sama sekali terlepas dari watak lokal. Namun, dapatlah disimpulkan bahwa Islam tradisional di Jawa menjadi lebih kuat terikat dengan pikiran Islam tradisional yang telah mapan dan paling banyak pengikutnya di dunia. Dengan kata lain, ketradisionalan mereka tidaklah karena terlalu banyaknya elemen-elemen non-Islam (baik yang berasal dari kepercayaa anisme dan Hindu Budisme) sebagaimana yang dikemukakan oleh Geertz, tapi karena keterikatan mereka terhadap aliran ulama Islam tradisional di seluruh dunia. 
Pada akhir abad ke-19 tersebut terdapat beberapa ulama kelahiran Jawa yang diakui kebesarannya di Tumur Tengah. Mereka menjadi pengajar tetap di Masjid Al-Haram di Mekah, seperti Syekh Nawawi (dari Banten) dan Syekh Mahfudz (dari Tremas). Satu hal yang cukup menarik dari perkembangan ini ialah, bahwa para pelajar dari berbagai daerah di Jawa yang melanjutan pelajaran di Mekah biasa baru dianggap dapat menyempurnakan pelajaran mereka setelah memperoleh bimbingan terakhir dari ulama kenamaan kelahiran Jawa ini. Hal ini menyumbang kepada proses homogenitas kitab-kitab yang dikapai di pesantren-pesantren di Jawa, dan dengan demikian proses homogenitas faham keagamaan dan kehidupan kultural para kiai di Jawa. Selain itu, semakin meningkatnya mutu keilmuan kiai, sebagai hasil dari lamanya mereka mengikuti pelajaran di Mekah, juga menyebabkan mutu pesantren meningkat, hingga dapat mengundang santri yang lebih banyak lagi. Para kiai juga banyak yang mulai memperkenalkan semangat dan sistem baru dalam pendidikan. Sistem madrasah diperkenalkan.

Perubahan penting terjadi dalam tahun 1910 di mana pesantrenpesantren (antara lain Pesantren Denanyar di Jombang) mulai membuka pondok untuk murid-murid wanita. Dalam tahun 1920-an beberapa pesantren (antara lain Pesantren Tebuireng di Jombang dan Pesantren Singosari, Malang) mulai mengajarkan pelajaran umum seperti Bahasa Indonesia, Bahasa Belanda, berhitung ilmu bumi dan sejarah.

Diperkenalkannya sistem madrasah, kesempatan pendidikan untuk murid wanita, dan pengajaran pengetahuan umum dalam lingkungan pesantren merupakan jawaban positif para kiai terhadap perubahanperubahan sebagai akibat politik Belanda di Indonesia sejak akhir abad ke-19. Mulai saat itu Belanda memperkenalkan sistem pendidikan Barat untuk penduduk pribumi. Sekolah-sekolah tipe Barat untuk penduduk pribumi ini dibuka dan dikembangkan oleh Belanda atas saran Snouck 
Hurgronje. Tujuannya ialah untuk memperluas pengaruh pemerintahan kolonial Belanda dan menandingi pengaruh pesantren yang luar biasa. Menurut Snouck Hurgronje, masa depan jajahan Belanda, tergantung kepada penyatuan wilayah tersebut dengan kebudayaan Belanda. Ini berarti pertama-tama westernisasi kaum ningrat dan priyayi di Jawa secara umum. Agar supaya penyatuan kebudayaan ini menjadi kenyataan, sistem pendidikan Barat harus diperluas agar lebih banyak lagi penduduk pribumi yang memperoleh pendidikan Belanda. Dasar pikirannya adalah bahwa sistem pendidikan barat merupakan sarana yang paling baik untuk mengurangi dan akhirnya mengalahkan Islam di wilayah jajahan Belanda tersebut. Dalam pertandingan antara Islam melawan daya tarik pendidikan Barat dan penyatuan kebudayaan, Islam pasti kalah. Snouck Hurgronje melihat gejala ini dengan adanya kecenderungan bahwa sampai tahun 1890 jumlah pesantren bertambah, sedangkan 20 tahun kemudian sekolah-sekolah tipe Belanda yang semakin dapat menarik murid yang lebih banyak.

Dengan diperkenalkannya sistem pendidikan Barat, para lulusan sekolah menengah dan universitas merupakan contoh ideal bagi golongan terdidik Indonesia, yang semakin menggantikan kedudukan kiai sebagai kelompok inteligensia dan pemimpin-pemimpin masyarakat.

Ini berarti bahwa anak-anak muda yang cerdas dan penuh ambisi akan semakin tertarik kepada pendidikan Barat, sebab mereka akan menikmati kesempatan memperoleh pekerjaan pada sektor birokrasi dan perusahaan moderen yang semakin terbuka bagi penduduk pribumi.

Walaupun pesantren-pesantren sudah banyak yang mengadakan perubahan-perubahan yang mendasar sebagai jawaban positif atas perkembangan ini, namun perubahan tersebut masih sangat terbatas. Ada 2 alasan utama yang menyebabkannya, yaitu : 1. Para kiai masih harus mempertahankan dasar-dasar tujuan pendidikan pesantren, yaitu 
bahwa pendidikan pada dasarnya ditujukan untuk mempertahankan dan menyebarkan Islam; dan 2. Mereka belum memiliki staf sesuai dengan kebutuhan pembaharuan untuk mengajarkan cabang-cabang pengetahuan umum.

Dengan berkembangnya sistem madrasah dalam lingkungan pesantren sejak permulaan abad ke-20, salah satu ciri penting daripada tradisi pesantren menghilang, yaitu tradisi "santri kelana". Diterapkannya sistem kelas yang bertingkat-tingkat dan ketergantungan kepada ijazah-ijazah formal sebagai tanda keberhasilan pendidikan seorang murid, menyebabkan seorang santri harus tinggal dalam satu pesantren saja untuk waktu bertahun-tahun. Di masa lampau, seorang santri, seperti kiai Wahab Hasbullah,akan berkelana dari satu pesantren ke pesantren lain untuk memuaskan kehausannya akan pengetahuan tanpa mempedulikan atau memikirkan ijazah formal. Menurut Dhofier, banyak kiai meyakinkannya bahwa kehidupan awal mereka di berbagai pesantren merupakan pengulangan yang berkali-kali dalam mendalami 4 atau 5 kitab Dasar dari guru yang berlainan sampai mereka betul-betul menguasai kitab-kitab tersebut. Pada waktu sekarang, seorang santri hampir tidak mungkin mengulangi sebuah kitab dengan kiai yang lain setelah ia menyelesaikan kitab tersebut di suatu madrasah.

Namun demikian, pesantren dapat memetik hasil yang sangat positif dari sistem madrasah, yaitu keberhasilan para kiai mengkonsolidasikan kedudukan pesantren dalam menghadapi perkembangan sekolah-sekolah Belanda. Dalam tahun 1920-an dan 1930-an, jumlah pesantren besar dan santri-santrinya melonjak berlipatganda. Sebelum tahun 1920-an, pesantren-pesantren besar mempunyai hanya sekitar 200 murid. Dalam permulaan tahun 1930-an banyak pesantren, seperti Pesantren Tebuireng, yang mempunyai jumlah murid lebih dari 1500 orang. Selain itu, walaupun jumlah sekolah- 
sekolah yang didirikan Belanda terus menerus bertambah, namun pendidikan tingkat menengah sampai tahun 1940 masih sangat terbatas bagi penduduk golongan Eropa. Profesor Kahin, seperti dikutif Dhofier, menulis sebagai berikut :

"Menjelang tahun 1940, ada sejumlah 88.223 penduduk pribumi yang terdaftar pada semua sekolah tipe Belanda tingkat dasar; 8.235 pada tingkat Mulo; dan 1.786 pada semua tingkat menengah ke atas. Dari jumlah tersebut, yang dapat menyelesaikan pelajarannya pada masing-masing tingkat pada tahun 1940 adalah 7.790, 1.130, dan 240. Perlu ditekankan di sini bahwa sampai dengan tahun 1940, pendidikan menengah tingkat atas, masih sangat terbatas untuk penduduk golongan eropa; 5.688 murid sekolah-sekolah tersebut adalah penduduk golongan eropa, sedangkan murid penduduk golongan pribumi hanya berjumlah 1.786." ${ }^{21}$

Pengaruh dominan pesantren mulai menurun secara drastis setelah penyerahan kedaulatan pada bulan Desember 1949. setelah penyerahan itu, pemerintah Indonesia mengembangkan pendidikan umum seluasluasnya, dan disamping itu jabatan-jabatan dalam administrasi modern terbuka luas bagi bangsa Indonesia yang terdidik dalam sekolah-sekolah umum itu. ${ }^{22}$

\section{KELEKATAN MASJID DAN PESANTREN}

Biasanya keberadaan masjid dalam sebuah komplek pesantren lebih dahulu ada dibandingkan dengan keberadaan pesantren itu sendiri. Oleh karenanya masjid merupakan instrumen awal sebuah pesantren. Karena di situ lah biasanya para kiai atau guru mendidik para muridmuridnya. ${ }^{23}$

\footnotetext{
${ }^{21}$ Lihat Zamakhsari Dhofier, hal 36-40.

${ }^{22}$ Ibid, hal 41

${ }^{23}$ Lihat penjelasan Zamakhsari Dhofier, hal 49.
} 
Menurut Mahfud Ziemek ${ }^{24}$, Selain fungsinya sebagai pusat upacara keagamaan dan shalat, masjid sekaligus merupakan juga tempat kehidupan umum komunal dan pendidikan. Teolog dan Filsuf dari Pakistan bernama Kausar menyimpulkan peranan "mosque as a education centre' berkembang dari tradisi Islam tertua dan menganggap tugas pendidikan sebagai perannya yang sentral, utama.

Demikianlah masjid-masjid sejak mula sekali merupakan pusat pendidikan. Orang yang berpengetahuan biasa tinggal di masjid. Masjid dapat disamakan dengan balairung kota, sekolah dan ada kalanya pondokan.

Peranan asal ini telah dimiliki oleh masjid dan rumah-rumah ibadah (langgar) sebagai unsur-unsur dalam pesantren tradisional. Di lingkungan warganya gedung-gedung tersebut sering dibangun swadaya dalam bentuk yayasan dan sumbangan yang juga turut bekerja secara langsung amat membantu dalam pelaksanaan untuk mewujudkannya. Partisipasi, peran serta secara suka rela dalam mendirikan rumah-rumah Allah adalah suatu kebiasaan yang meluas dan dianggap berpahala bagi kehidupan di akhirat.

Sebagai santri (muslim yang taat) mereka mengunjungi masjidmasjid sebagai pusat upacara keagamaan untuk menegakkan shalat lima waktu sehari sembari dalam hubungan dengan tindakan tata cara ritual lainnya. Berbagai macam kegiatan agama lainnya terutama hari-hari raya keagamaan (misalnya dalam bulan Puasa dan Lebaran) diselenggarakan di sini.

Karena dalam Islam masalah-masalah agama dan negara tidak terpisah dengan ketat, maka masjid-masjid sekaligus merupakan tempat-

\footnotetext{
${ }^{24}$ Lihat Manfred Ziemek, Pesantren dalam perubahan social, (Jakarta: P3M, cet. 1, 1986), hal 111-112. dan karya ini merupakan desertasi Doctor pada Universitas di Jerman.
} 
tempat kehidupan warga umum. Kepala masjid (penghulu, kadangkadang disebut juga Imam) adalah seorang tokoh dan pemegang fungsi komunal yang penting, yang misalnya menentukan atau menengahi perselisihan hukum, melaksanakan maupun mensahkan sebuah upara pernikahan maupun perceraian.

Selanjutnya, khathib dan muadzin adalah pejabat masjid. Dalam wilayah yang lebih luas masjid sering juga mempunyai fungsi administrasi, dan menjadi kantor kementrian agama.

Lebih tersebar dibandingkan dengan masjid adalah rumah-rumah ibadah, yang berbeda-beda namanya disebut di masing-masing daerah, yakni langgar, tajug, sura atau surau, bala atau mushollah. Semua ini ditemukan di banyak tempat umum : di statiun kereta api, sekolah, bandar udara, kantor pemerintah, namun juga sebagai bagian terpisah dari rumah-rumah pribadi, terutama penduduk Islam yang kaya.

\section{KURIKULUM PELAJARAN PESANTREN}

Amat sulit untuk menggambar tujuan pendidikan yang seragam dari sejumlah besar bentuk-bentuk pesantren. Akibatnya timbul kesulitan yang lebih besar lagi untuk menentukan kurikulum dan bahan pelajaran secara umum. Sebagaimana ditekankan oleh Chirzin, hal ini justru merupakan ciri pesantren tradisional, untuk bekerja tidak berdasarkan sasaran pendidikan yang dirumuskan secara eksplisit, kurikulum yang tetap maupun jadwal studi, sebagai tanda bagi kebebasan tujuan pendidikan. Di sini belajar dan mengajar terutama dipandang sebagai bentuk ibadah kepada Tuhan, artinya suatu kegiatan yang berpahala dan tidak harus berorientasi kepada tujuan-tujuan duniawi.

Namun, terdapat beberapa kesamaan sehubungan isi pelajaran dan didaktik yang khas, yang dalam pengaturannya amat tergantung kepada 
pengetahuan dan pengalaman mengajar maupun kesadaran kiai, yang akhirnya menentukan organisasi, penyelenggaraan pelajaran.

Hampir semua pesantren pertama-tama mengajarkan pelajaran tingkat dasar dalam tulisan dan fonetik Arab, agar santri muda dapat membaca dan mengulang tulisan-tulisan Arab klasik Karena melafazkan ayat-ayat Qur'an dalam bahasa Arab itu sendiri dianggap berpahala dan merupakan sebagian dari suatu ibadah walaupun isinya tidak dimengerti, di sini terdapat motif, untuk menghafalkan ayat suci ini dan karenanya harus melafazkannya secara hafalan di luar kepala. "Tingkatan pengetahuan'. ini namun lebih khas bagi peserta kelompok pengajian yang dilesenggarakan pesantreh bagi penduduk desa.

Bagi para siswa santri adalah penting untuk pada permulaan menguasai pengetahua yang cukup tentang bahasa Arab klasik, sebagai syarat untuk mendalami ayat-ayat keagamaan, filsafat, hukum dan ilmiah. Studi bahasa Arab (tulisan, intonasi, tatabahasa, sintaksis dan semantik) sebagai ilmu penolong sangat memakan waktu dan merentang sepanjang keseluruhan masa studi sejalan dengan bertambahnya tingkatan, artinya berlangsung secara simultan dengan mempelajari Kitab. Para Santri mengerjakan sendiri naskah-naskah agama, filsafat dan ilmiah secara berturut-turut, sejalan dengan meningkatnya pemahaman: membaca, menerjemahkan, mengerti, menafsirkan. Akibat seringnya terdapat kekurangan pengetahuan bahasa Arab, tradisi lisan dalam penyampaian ayat di nilai tinggi. Santri tingkat lanjutan, guru atau kiai membaca naskah/ayat tersebut kata demi kata dan sekaligus menerjemahkannya. Sebab kebanyakan santri muda belum mengerti bahasa Arab, mereka menghafalkannya di luar kepala, atau mencatat keterangannya dalam bahasa Jawa dengan menggunakan huruf Arab (pegon). 
Adalah termasuk ke dalam cara jadwal pelajaran dari banyak pesantren, bahwa dengan cara itu naskah dasar agama (Qur'an, Hadist) maupun Kitab Kuning dipelajari oleh santri pemula.

Spektrum naskah agama, yang harus dibaca atau dipelajari oleh seorang santri, menurut Dhoifer,mencakup kelompok berikut :

1. Sintaksis Arab (nahwu) dan morfologi (sarf).

2. Hukum Islam (fiqh).

3. Sistim yurisprudensi Islam (usul fiqh).

4. Hadist (kumpulan kata-kat dan perbuatan Nabi Muhammad maupun tradisi yang beranjak dari sana).

5. Tafsir Qur'an.

6. Teologi Islam (Tauhid).

7. Sufisme/mistik (Tasawuf).

8. Berbagai naska tentang sejarah Islam (tarikh) dan retorik (balaghah).

Studi tentang tentang bagian pengetahuan ini harus berlangsung sejalan dengan bertambahnya tingkatan, sehingga santri untuk itu pada mulanya mengerjakan, mempelajari naskah-naskah dasar, lalu lanjutannya serta akhirnya naskah-naskah tingkat tinggi.

Sesuai dengan tingkatan yang amat berbeda-beda dan spesialisasi pesantren biasanya hanya dapat memberikan sebagian dari spektrum ilmu yang disebut sebelum ini, maka santri tingkat lanjutan, bila mereka mendambakan untuk memperdalam ilmunya, kerapkali harus pindah ke pesantren lain. Oleh karena tidak ada ijazah yang dikeluarkan, siswa menyebut jumlah dan tingkatan naskah (Kitab) yang telah ia pelajari tuntas dan sering hafalan di luar kepala. Hal ini dimaksudkan sebagai indikator, tanda, penguasaan bidang-bidang ilmu tertentu.

Tidak hanya studi, mempelajari naskah-naskah agama klasik, namun mungkin masih lebih kuat adalah suasana agama dan sosial sebuah pesantren, di tambah kegiatan ekstra kurikuler ikut 
membantunya, dalam mencapai nilai ideal pendidikan dalam perkembangan pribadi. Hidup dan belajar dalam pondok membentuk santri secara kuat: Cara hidup yang sederhana dan asketik (disiplin) dalam kelompok santri, tempat 10 hingga 12 siswa tingga dalam rumah dan kamar tidur yang kecil, memecahkan permasalahan dan mengaturnya secara bersama, menyusun waktu luang secara bersama, melakukan olahraga dan latihan silat, shalat bersama, Suasana yang diciptakannya menguntungkan perkembangan suatu semangat korps. Tambahan lagi dalam pesantren yang agak besar administrasi santri sendiri, dengan mereka mengatur tanggungjawab sendiri untuk sebagian besar masalah yang berhubungan dengan kesiswaan.

Prakarsa, rasa tanggung jawab akan masalah-masalah pondok dan kawan-kawan menjadi komponen suatu latihan kepemimpinan tidak resmi. Para santri tingkat lanjutan mendirikan dan memimpin kelompok belajar bagi santri yang lebih muda dan sekaligus menjadi guru di desadesa sekitarnya.

Dalam "pesantren modern" program pendidikan dapat jauh lebih besar. Sebagai contoh di sini disebutkan spektrum pendidikan pesantren Pabelan, yang terdiri dari program kursus yang tetap, sebagian dalam bentuk pelajaran kelas, sebagian lain dalam kelompok belajar terbuka. Spektrum pelajaran dilengkapi dengan apa yang disebut acara "ekstra kurikuler", seperti olahraga, pendidikan budaya, latihan kerajinan, keterampilan pekerjaan, kelompok kerja untuk kegiatan pembangunan desa. Ekstra kurikuler ditetapkan sebagai pelengkap dan tidak diwajibkan untuk mengikutinya. Lain dengan pesantren klasik, bagian keagamaan dikurangi sehingga Cuma 30\% dari kurikulum. Bahasa Inggris dan Arab ditekankan (25\%), sedangkan sebagian besar kurikulum ditutup dengan mata pelajaran umum. 


\section{PESANTREN DAN KITAB KUNING}

Masdar Mas'udi menyebutkan, pada mulanya, masyarakat Pesantren sendiri tampaknya tidak mengerti kenapa kitab-kitab yang mereka kaji dan pedomani di sebut orang dengan kitab kuning. Kemungkinan besar sebutan itu datang dari pihak orang luar dengan konotasi yang sedikit mengejek. Terlepas dengan maksud apa dan oleh siapa di cetuskan, istilah itu kini telah semakin memasyarakat baik di luar maupun di dalam lingkungan pesantren.

Dalam kegunaannya, nama itu lazim dipakai untuk menunjuk karya-karya tulis (tuilis Arab) yang disusun para sarjana Islam abad pertengahan, dan karena itu sering disebut pula dengan kitab kuno. Kitab-kitab itu meskipun dari sudut kandungannya komprehensif dan dapat di katakan berbobot akademis, tapi dari segi sistimatika penyajiaanya nampak sangat sederhana. Misalnya, tidak dikenal tandatanda bacaan seperti titik, koma tanda tanya dan sebagainya. Pergeseran dari satu sub ke sub topik yang lain, tidak dengan menggunakan alenia baru, tapi dengan pasal- pasal atau kode sejenis seperi; tatimmah, muhimmah, tanbih, far', dan sebagainya.

Isi yang disajikan kitab kuning hampir selalu terdiri dari dua komponen; pertama komponen matan dan lainnya adalah syarah. Matan adalah isi inti yang akan di kupas oleh syarah. Dalam layout-nya, matan diletakan di luar garis segi empat yang mengelilingi syarah. Ciri lain, penjilidan kitab-kitab ini biasanya dengan siistem koresan (karasah; Arab ), dimama- lembaran-lembarannya dapat di pisah-pisahkan sehingga lebih memudahkan pembaca untuk menelaahnya sambil santai atau tiduran, tanpa harus menggotong semua tubuh kitab yang kadang mencapai ratusan halaman. Surat kabar, satu-satunya jenis bacaan populer pada masa kini adalah penganut sistem korasan yang fanatik. Sementara itu kenapa diberi sebutan kuning karena memang kertas yang 
di pakai umumnya berwarna kuning, atau putih putih tetapi karena di makan usia maka warna itupun telah berubah menjadi kuning. ${ }^{25}$

Di kalangan Pesantren, kedudukan kitab kuning ini saling melengkapi dengan kedudukan kyai. Kitab kuning merupakan himpunan kodifikasi tata nilai yang dianut masyarakat pesantren, sedang kyai adalah personafikasi yang utuh (atau yang dianggap demikian) dari sistem tata nilai itu. Kedua-duanya hampir tak terpisahkan. Seorang kyai baru disebut kyai. Apabila ia benar-benar telah memahami dan mendalami isi ajaran-ajaran yang terdapat dalam kitab kuning, dan mengamalkannya dengan penuh kesungguhan dan keikhlasan. Kadar kedalaman dan pengamalan terhadap kitab kuning adalah salah satu kriteria yang paling representatif untuk mengukur derajat seorang kyai atas kyai lain. Dan dimata santri-meskipun sekarang tidak lagi dominansuatu kitab kuning akan di jadikan pedoman berfikir atau tingkah laku apabila telah di kajikan dihadapan kyai, atau sekurang-kurangnya sang kyai panutan telah menyatakan ijazahnya (izinnya) untuk itu. Inilah sebabnya mengapa seorang santri senior yang telah mampu membaca sendiri kitab-kitab, acapkali masih tetap merasa perlu untuk mengkajikannya dihadapan seorang kyai yang menurut si santri telah mengejawantahkan isi kandungan dan piwulang (ajaran) kitab yang akan disajikan itu.

Tapi apa yang ingin dikemukakan di sini bukanlah ganbaran dari konsep pemikiran seluruh kitab yang dapat dikategorikan sebagai kitab kuning. Ada dua alasan mengapa itu tidak mungkin, setidak-tidaknya bagi penulis sendiri. Pertama, jumlah kitab kuning itu sendiri sangat beragam. Syhdan, jika di sebut kitab kuning di dalam tulisan ini, maka maksudnya adalah kitab kuning yang beredar secara merata di kalangan

\footnotetext{
${ }^{25}$ Lihat Masdar F. Mas'udi, Pergulatan Pesantren Membangun dari Bawah, (Jakarta: 1985, P3M, ) hal 55-56.
} 
masyarakat pesatren. Inipun sesungguhnya belum berarti gambaran yang bisa dikemukakan di sini dapat digeneralisasikan kepada semua kitabkitab itu. Sebab meskipun dari segi pola pikir dan pandangannya kurang lebih sama, tapi sejauh mana suatu kitab dapat dikatakan populer dikalangan masyarakat pesantren. Kriterianya pun bisa berbeda-beda. Ada kitab yang di kalangan awam pesantren populer, tapi di kalangan elit (khawas)-nya tidak; dan sebaliknya. Kendatipun seperti dikatakan di atas, khawas itu panutan si awam, dan khawas sendiri adalah pencerminan dari kitab-kitab yang di bacanya. ${ }^{26}$

Di kalangan masyarakat pesantren masih tetap kukuh keyakianan bahwa ajaran -ajaran yang di kandung dalam kitab kuning tetap merupakan pedoman hidup dan kehidupan yang sah dan relevan. Sah, artinya ajaran-ajaran itu di yakini bersumber pada kitab Allah dan Sunnah Rasul-Nya, dan tidak ketinggalan sebagai unsur pelengkap adalah piwulang-piwulang (ajaran) luhur dari ulama-ulama salaf yang shalih. Relevan artinya bahwa ajaran-ajaran itu masih tetap cocok dan berguna untuk meraih kebahagiaan hidup kini, maupun nanti. Di sinilah letak perbedaan antara masyarakat pesantren yang oleh sementara pengamat disebut 'tradisional' dan masyarakat Islam ain yang disebut 'modern'. (dikotomi ini ,belakangan semakin banyak mendapat kritikan). Masyarakat pesantren, pengikut kitab kuning, mempercayai bahwa pedoman hidup adalah kitabullah dan sunnah Rasulullah, tetapi mereka hanya akan mempedominya melalui tafsiran-tafsiran dan penjabaranpenjabaran yang telah di upayakan oleh ulama-ulama yang dinilai terpercaya. Sementara pihak lain yang disebut kelompok modern ingin mempedomi kedua sumber itu, bukan dengan alat bantu tafsiran ulamaulama tadi, melainkan melalui tafsiran-tafsiran atau penjabaran-

\footnotetext{
${ }^{26}$ Ibid hal 57.
} 
penjabaran yang diupayakan sendiri. Dengan lain perkataan, perbedaan itu kurang lebihnya hanya berkisar pada soal cara, bukan pada tujuan. Tapi dengan latar belakang ini, maka kelompok yang berpredikar' modern itu hampir-hampir tidak dapat memberikan apresiasi terhadap kitab kuning, juga para ulama yang telah menyusunnya sesuatu yang bertolak belakang dengan sikap masyarakat pesantren yang bercorak 'tradisional' itu. ${ }^{27}$

\section{MODEL-MODEL PESANTREN}

Meskipun setiap pesantren mempunyai ciri-ciri dan penekanan tersendiri, hal itu tidaklah berarti bahwa lembaga-lembaga pesantren tersebut benar-benar berbeda satu sama lain, sebab antara yang satu dengan yang lain masih saling kait mengait. Sistem yang digunakan pada suatu pesantren juga diterapkan di pesantren lain, dan sebaliknya.

Karena itu, sebenarnya amat sulit untuk menentukan dan menggolongkan lembaga-lembaga pesantren ke dalam tipologi tertentu, misalnya :pesantren salaf dan khalaf atau pesantren tradisional dan modern. Tidak ada dasar bagi penggolongan tersebut, baik dari segi sistem yang digunakan atau dari model kelembagaannya. Buktinya, sistem pengajian yang diterapkan pada sebuah pesantren "salaf" ternyata juga dipakai di pesantren "modern". Begitu pula model kelembagaan pesantren modern banyak digunakan di pesantren salaf.

Kesulitan serupa juga terjadi tatkala kita hendak mengkategorikan pesantren sebagai besar, sedang, atau kecil. Masalah yang muncul misalnya berapa jumlah santri pada suatu pesantren sehingga dapat digolongkan sebagai pesantren besar, sedang, atau kecil. Tidak ada patokan baku dalam hal ini.

\footnotetext{
${ }^{27}$ Ibid hal 57.
} 
Terlepas dari kesulitan tersebut, untuk lebih mudahnya penulis mengikuti klasifikasi yang diberikan Zamakhsyari Dhofier. Menurutnya, sebuah pesantren digolongkan kecil bila memiliki santri di bawah 1.000 orang dan pengaruhnya hanya sebatas kabupaten. Pesantren sedang memiliki santri antara 1.000-2.000 orang yang pengaruh dan rekruitmen santrinya meliputi beberapa kabupaten .Sedangkan pesantren besar memiliki santri lebih dari 2.000 orang dan biasanya berasal dari beberapa kabupaten dan propinsi. Bahkan, beberapa pesantren besar seperti Pondok Modern Gontor dan Lirboyo Kediri - keduanya di Jawa Timur- memiliki popularitas yang menarik santri tidak hanya dari Tanah Air, melainkan juga negara-negara lain seperti Malaysia, Brunei, Singapura, Thiland, dan Filipina. ${ }^{28}$

\section{Pesantren Salaf}

Menurut Zamalkhsyari Dhofier, pesantren salaf adalah lembaga pesantren yang mempertahankan pengajaran kitab-kitab Islam klasik (salaf) sebagai inti pendidikan. Sedangkan sistem madrasah ditetapkan hanya untuk memudahkan sistem sorogan yang dipakai dalam lembagalembaga pengajian bentuk lama, tanpa mengenalkan pengajaran pengetahuan umum. ${ }^{29}$

Sistem pengajaran pesantren salaf memang lebih sering menerapkan model sorogan dan weton. Istilah weton berasal dari bahasa Jawa yang berarti waktu. Disebut demikian karena pengajian model ini dilakukan pada waktu-waktu tertentu, biasanya sesudah mengerjakan shalat fardhu.

Sistem weton atau juga dikenal dengan istilah bendongan adalah model pengajian yang dilakukan seperti kuliah terbuka yang diikuti oleh

\footnotetext{
${ }^{28}$ Wahjoetomo, Ibid, hal 83.

${ }^{29}$ Zamaksyari Dhofier, Ibid, hal 41.
} 
sekelompok santri sejumlah 100-500 orang atau lebih. Sang kiai membaca, menerjemahkan, menerangkan, dan sekaligus mengulas kitabkitab salaf berbahasa Arab yang menjadi acuannya. Sedangkan para santri mendengarkan dan memperhatikan kitabnya sambil menulis arti dan keterangan tentang kata-kata atau pemikiran yang sukar.

Termasuk dalam kelompok sistem bendongan atau weton ini adalah halaqah, yaitu model pengajian yang umumnya dilakukan dengan cara mengitari gurunya. Para santri duduk melingkar untuk mempelajari atau mendiskusikan suatu masalah tertentu di bawah bimbingan seorang guru atau kiai.

Sedangkan pada sistem sorogan, para santri maju satu persatu untuk membaca dan menguraikan isi kitab di hadapan seorang guru atau kiai. Sistem ini amat bagus untuk mempercepat sekaligus mengevaluasi penguasaan santri terhadap kandungan kitab yang dikaji. Akan tetapi, sistem ini membutuhkan kesabaran, ketekunan, ketaatan, dan kesiplinan yang tinggi dari para santri. Model ini biasanya hanya diberikan kepada santri pemula yang memang masih membutuhkan bimbingan khusus secara insentif. Pada umumnya pesantren lebih banyak menggunakan model weton karena lebih cepat dan praktis untuk mengajar banyak santri.

Selain dua sistem tersebut, pesantren salaf juga kerap menggunakan model musyawarah. Biasanya meteri telah ditentukan lebih dulu dan para santri dituntut menguasai kitab-kitab rujukan. Kiai memimpin kelas musyawarah sebagaimana moderator memandu seminar. Model ini lebih bersifat dialogis, sehingga umumnya hanya diikuti oleh para santri senior. Tujuannya untuk melatih dan menguji kemampuan dan keterampilan para santri dalam menangkap dan memahami sumber-sumber argumentasi dari kitab-kitab Islam klasik (kitab kuning). 
Akan tetapi dewasa, ini kalangan pesantren --termasuk pesantren salaf-- mulai menerapkan sistem madrasati atau model klasikal. Kelaskelas dibentuk secara berjenjang dengan tetap memakai kurikulum dan meteri pelajaran dari kitab-kitab kuning, dilengkapi pelatihan keterampilan seperti menjahit, mengetik, dan bertukang.

Kurikulum sistem madrasati pesantren salaf masih sangat umu, tidak dirumuskan secara jelas dan terperinci. Akan tetapi yang jelas, semua pelajaran tersebut telah mencakup segala aspek perbuatan santri dalam sehari semalam. Kurikulum yang berhubungan dengan materi pengajian berkisar pada ilmu-ilmu agama dengan segala bidangnya, terutama pengetahuan yang berhubungan dengan bahasa Arab (nahwu, sharaf, dan ilmu-ilmu alat lainnya), ilmu yang berhubugan dengan syariat (ilmu fikih ibadah dan mualamah), ilmu-ilmu yang berhubungan dengan Al-Qur'an beserta tafsir-tafsirnya, hadist dengan musthalahnya, dan ilmu tauhid. Terkadang dilengkapi dengan musthalahnya, dan ilmu tauhid. Terkadang dilengkapi pula dengan ilmu mantiq (logika), tarikh (sejarah), dan tasawuf untuk para santri senior.

Kendati demikian, tidak berarti ilmu-ilmu keislaman yang diajarkan di pesantren-pesantren sama dan seragam. Pada umumnya, setiap pesantren mempunyai penekanan atau ciri-ciri tersendiri dalam hal ilmu-ilmu yang diberikan. Misalnya: Pesantren Gontor lebih menekankan penguasaan bahasa arab dan inggris, sedangkan Pesantren Lirboyo Kediri dan Pesantern Langitan Tuban dengan ilmu-ilmu alatnya. $^{30}$

Karenanya, sungguh sulit. Bahkan, mustahil menyamaratakan sistem dan kurikulum pesantren sebagaimana pernah di usulkan beberapa tahun lalu. Apalagi realitas dunia pesantren menunjukan

\footnotetext{
${ }^{30}$ Ibid hal 85.
} 
bahwa kiai sebagai pengasuh mempunyai kekuasaan "mutlak" atas lembaganya, sehingga tidak bisa di campuri pihak lain.Penulis berpandangan,biarkan mereka berjalan sendiri-sendiri dengan ciri khasnya. Bahkan menurut Habib Chirzin, ketidak seragaman tersebut merupakan ciri pesantren salaf, sekaligus tanda atas kebebasan dari tujuan pendidikan (Habib Chirzin,1974).

Dari sisi kelembagaan dan status pesantren, semua bangunan yang berada di lokasi pesantren umumnya adalah milik kiai. Kiai adalah pemilik dan penguasa tunggal di pesantren. Beliaulah yang menentukan segala kebijakan yang berlaku di dalamnya. Para ustadz dan pembantu lainnya berkedudukan sebagai tenaga operasional.

Oleh karena itu, kiai mempunyai kedudukan khusus. Ini karena dalam pesantren salaf, segala bangunan dan pembiayaan pesantren memang didanai dari uang pribadi kiai. Dialah yang mendirikan, membangun, dan menghidupi jalannya kegiatan pesantren. Sehingga, wajar bilai kiai mempunyai pengaruh dan kekuasaan yang besar atas pesantrennya. Sebagaimana kita lihat dalam sebuah perusahaan - kalau boleh disamakan--, penanam saham terbanyak adalah yang paling menentukan kebijakan perusahaan.

Mengapa kiai mesti bersusah payah membangun pesantren? Menurut Zamakhsyari Dhofier, minimal ada tiga alasan yang dapat dikemukakan. Pertama, kemahsyuran seorang kiai dan kedalaman ilmunya tentang seluk beluk ajaran Islam telah menarik masyarakat (santri) dari berbaga daerah yang jauh. Untuk menggali ilmu sang kiai secara teratur dan dalam jangka waktu lama, para santri harus meninggalkan kampung halaman dan menetap di dekat rumah kiai. Itu berarti ia harus memondok di lokasi pesantren.

Kedua, para kiai -karena pengaruh ajaran hidup zuhudmenghindari keterkaitan terhadap gaya hidup mewah. Agar lebih terjaga 
dari godaan-godaan duniawi, mereka menetap di desa-desa yang jauh dari keramaian. Di desa kiai tersebut, pada umumnya tidak tersedia akomodasi yang dapat menampung santri-santri yang ingin belajar dan mengabdi kepadanya, sehingga perlu dibulatkan asrama khusus bagi para santri untuk mempermudah hubungan dan keperluan mereka.

Ketiga, sikap timbal balik antara kiai dan santri. Santri menanggap sang kiai sebagai ayahnya sendiri dan kiai memandang para santri sebagai anak-anaknya yang dititipkan Allah, karena itu harus senantiasa dilindungi. Sikap timbal balik ini akhirnya menimbulkan keakraban dan kebutuhan untuk saling dekat satu sama lain. Sikap ini juga menimbulkan rasa tanggung jawab kiai untuk menyediakan tempat tinggal bagi para santri serta menciptakan rasa pengabdian yang dalam pada diri santri terhadap kiainya. Sehingga pada akhirnya para kiai memperoleh sumber tenaga bagi kelangsungan hidup pesantrennya. ${ }^{31}$

Kondisi pesantren salaf dan khalaf di Indonesia berbeda dengan pesantren di negara-negara Islam yang lain. Misalnya di Mekah dan Medinah, syekh (kiai) menetap di kota dan mengajarkan ilmu-ilmu agama di Masjidil Haram dan Masjid Nabawi. Para santri yang datang dari jauh menetap di koloni-koloni atau menyewa tempat tinggal di dekat gurunya, yang biasanya memang tersedia cukup banyak. Begitu pula di al-Azhar, Kairo, Mesir. Berbeda dengan pesantren, al-Azhar bermula dari sistem pendidikan masjid tradisional. Pemerintah memegang inisiatif penting dalam pembangunan lembaga pendidikan alAzhar, tetapi kemudian menjadi instansi milik masyarakat sepenuhnya.

Pentingnya pondok sebagai asrama para santri bergantung pada jumlah santri yang datang dari daerah jauh. Pada pesantren kecil, yang kebanyakan para santrinya tidak berasal dari daerah jauh, banyak santri

\footnotetext{
${ }^{31}$ Ibid hal 86.
} 
yang menetap di rumahnya sendiri. Mereka menggunakan pesantren hanya untuk belajar atau kegiatan lain yang terkait. Sedangkan di pesantren besar seperti Pesantren Tambakberas Jombang, para santri tidak boleh menetap di luar komplek pesantren, kecuali yang berasal dari desa-desa sekitarnya. Alasannya, agar kiai dapat mengawasi dan menguasai mereka secara mutlak. Ini karena kiai tidak hanya berfungsi sebagai guru yang mentransfer ilmu, tetapi juga pengganti orang tua yang bertanggung jawab terhadap pembinaan perilaku dan moral santri. $^{32}$

\section{Pesantren Khalaf (Modern)}

Pesantren khalaf atau modern adalah lembaga pesantren yang memasukkan pelajaran umum dalam kurikulum madrasah yang dikembangkan, atau pesantren yang menyelenggarakan tipe sekolahsekolah umum seperti SMP, SMU, dan bahkan perguruan tinggi dalam lingkungannya.

Akan tetapi, tidak berarti pesantren khalaf meninggalkan sistem salaf. Ternyata hampir semua pesantren modern --meskipun telah menyelenggarakan sekolah-sekolah umum-tetap menggunakan sistem salaf di pondoknya. Misalnya, Pondok Pesantren "Bahrul Ulum", Tambakberas. Pesantren ini menyelenggarakan pendidika formal yakni dari Madrasah Al-Qur'an hingga Muallimin-Muallimat, dan dari SMP hingga Universitas Bahrul Ulum. Akan tetapi, di lingkungan pondoknya masih menerapkan sistem salaf. Setiap selesai menunaikan shalat wajib, para santri menelaah kitab Nihayatuz-Zain, Sahih Bukhari, Sahih Muslim, Fathul Wahhab, Fathul Mu'in, Tafsir Munir, dan sebagainya dengan sistem weton atau sorogan.

\footnotetext{
${ }^{32}$ Ibid hal 87.
} 
Dibandingkan dengan pesantren salaf, pesantren khalaf mengantongi satu nilai plus karena lebih lengkap materi pendidikannya yang meliputi pendidikan agama dan umum. Para santri pesantren khalaf diharapkan lebih mampu memahami aspek-aspek keagamaan dan keduniaan agar dapat menyesuaikan diri secara lebih baik dengan kehidupan modern daripada alumni pesantren salaf.

Meskipun begitu, hendaklah jangan diartikan bahwa pesantren khalaf lebih bermutu daripada pesantren salaf. Ini karena dengan masuknya ilmu-ilmu umum dan berbagai keterampilan ke pesantren, bila tidak waspada, identitas asli pesantren sebagai lembaga pencetak ulama serta pengembang, penyebar, dan pelestari jaran-ajaran Islam akan memudar. Kegiatan pendalaman ajaran Islam akan tergeser oleh kegiatan-kegiatan lain yang sebenarnya lebih cocok dilakukan oleh lembaga lain. Dikhawatirkan pada akhirnya pesantren tidak berbeda dengan lembaga-lembaga pendidikan umum.

Bila hal itu sampai terjadi, maka pesantren yang memasukkan ilmu-ilmu umum dan berbagai keterampilan akan rugi dan tidak dipandang lagi oleh masyarakat. Ada dua penyebab yang perlu diperhatikan.

Pertama, pesantren akan kehilangan jati diri. Kualitas pengkajian ilmu-ilmu agama yang merupakan materi utama di pesantren akan menjadi dangkal. Bahkan mungkin hasil kajiannya akan kalah berbobot dengan studi Islam yang dilakukan para mahasiswa dengan halaqahhalaqah-nya, seperti yang sedang trend di kampus-kampus saat ini.

Kedua, dalam penguasaan keterampilan dan ilmu-ilmu umum, alumni pesantren kemungkinan kalah dibandingkan dengan alumni lembaga keterampilan atau lembaga pendidikan umum yang sejak semula menekankan materi-materi tersebut. Sebagai perbandingan, dapat dilihat pada Madrasah-madrasah Aliyah yang juga mengajarkan 
ilmu-ilmu agama dan umum. Pada umumnya, kualitas lulusannya belum memuaskan. Dalam penguasaan ilmu umum, terutama ilmu-ilmu eksakta, mereka kalah dengan lulusan SMU Negeri. Sedangkan dalam penguasaan ilmu-ilmu keislaman, mereka harus mengakui kelebihan para santri pesantren salaf. Oleh karena itu, Madrasah-madrasah Aliyah ini masih perlu penyempurnaan secara berkelanjutan.

Mengenai hubungan kiai dengan kelembagaan pada pesantren khalaf --berbeda dengan pesantren salaf-- yakni segala kekayaan dan bangunan pesantren umumnya tidak dianggap sebagai milik kiai, melainkan milik masyarakat. Sebab pada pesantren khalaf, pembiayaan pembangunan pesantren tidak hanya dari sang kiai, tetapi juga dari masyarakat. Banyak komplek pesantren yang berstatus wakaf, baik dari kiai terdahulu maupun orang-orang kaya di sekitarnya.

Meskipun demikian, dari segi karisma dan 'kekuasaan', tidak berarti peran kiai berkurang. Pada lembaga-lembaga pesantren yang berasal dari harta wakaf atau lainnya, --sama seperti pada pesantren salaf-- kiai tetap mempunyai kekuasaan mutlak atas kepengurusan pesantren. Para kontributor juga beranggapan bahwa kiai berhak atas dana dari masyarakat. Dana itu dianggap sebagai milik Allah, dan para kiai diakui sebagai pribadi yang --atas nama Allah atau agama-mengurus dana dari masyarakat tersebut. Dalam praktiknya, jarang sekali diperlukan campur tangan masyarakat dalam pengelolaan danadana itu. ${ }^{33}$

Pesantren terlihat unik dan menarik, memiliki ciri khusus dan ada tradisi tersendiri yang berbeda dengan model pendidikan umum. Sistem pengajaran yang dilakukan di pesantren seringkali tidak menggunakan kurikulum, atau target tertentu dan kurikulum semuanya diserahkan

\footnotetext{
${ }^{33}$ Ibid, hal 87-89.
} 
pada masing-masing kiai. Dan umumnya materi yang disampaikan itu lebih banyak bermuatan bahasa Arab 'kitab kuning'. Dan seringkali keberadaan masjid dalam sebuah komplek pesantren lebih dahulu ada dibandingkan dengan keberadaan pesantren itu sendiri. Oleh karenanya, masjid merupakan instrumen awal sebuah pesantren. Karena di situ lah biasanya para kiai mendidik para santrinya. Dan pesantren secara umum terbagi dalam dua model. Model tradisional dan modern. Wa Allahu 'alam bishshawnab.

\section{DAFTAR PUSTAKA}

Ahmad Muthohar, AR., Ideologi Pendidikan Pesantren (Semarang: 2007, Pustaka Rizki Putra), cet. Ke-1.

Bruisessen, Martin Van, Kitab Kuning Pesantren dan Tarekat Tradisi-tradisi Islam di Indonesia, (Bandung: Mizan, 1999, cet. 3).

Dhofier, Zamakhsari, Tradisi Pesantren Studi tentang Pandangan bidup Kyai, Jakarta: LP3ES, 1994, cet. ke-6.

Ensiklopedi Islam (Jakarta: 1993, Ichtiar van Hoeve), cet. 1.

Jabali, Fuad dan Jamhari (penyu), IAIN Modernisasi Islam di Indonesia (Jakarta: 2002, Logos).

Media Dakwah No. 70-79, tahun 1980-81.

Pesantren, P3M, No. 1, Vol. III, 1986.

Prisma, LP3ES, No. 2, Februari 1986.

Republika, Khazanah, Geneologi Sejarab Pesantren, Senin, 4 Februari 2008.

Wahjoetomo, Perguruan Pesantren Pendidikan Alternatif Masa depan, (Jakarta: 1997, GIP, Cet. 1).

Ziemek, Manfred, Pesantren dalam perubahan social, (Jakarta: P3M, cet. 1, 1986). 